\title{
ORIGEM E FUNDAÇÃO DO SERVIÇO DE PROTEÇÃO AOS ÍNDIOS (V).
}

\section{(Continuação) .}

\section{Capftulo V}

\section{A DIFUSÃO DO DEBATE INDfGENA.}

E' preciso dar-se conta que no Brasil da época estudada aqui, como mesmo ainda hoje se observa, a maior parte ds figuras importantes do mundo profissional, tanto cientistas como políticos, clérigos, oficiais ou eruditos, eram sócios de uma ou mais das sociedades científicas de suas cidades ou de seus Estados. Amiude freqüentavam as sessões de dois ou três grupos diferentes e, além disso, eram membros correspondentes de várias outras sociedades, localizadas em regiões distantes do Brasil e em centros culturais da América espanhola, dos Estados Unidos e da Europa. Quando as figuras influentes nas diferentes profissões desejavam externar seus pontos de vista sôbre um determinado assunto, ou dar publicidade aos seus estudos científicos mais recentes, suas criações literárias ou monografias históricas, geralmente os apresentavam primeiro diante suas respectivas sociedades. Depois, freqüentemente, tais estudos eram impressos e publicados nas excelentes revistas dos diversos institutos.

Assim, no Brasil mais do que nos Estados Unidos, a apresentação pública de um ponto de vista referente a uma questão controvertida podia fácil, e ràpidamente, atrair um instituto poderoso para a discussão geral. Como vimos, a tradução portuguêsa da declaração de Hermann von Ihering apareceu primeiro nas páginas da revista de seu próprio museu. Assim, o Museu Paulista, desde o comêço, estava profundamente envolvido no debate indígena. Além disso, seu diretor, de origem alemã, continuava usando as publicações anuais do Museu como porta-voz de suas opiniões pessoais a respeito da questão 
ia pacificação e assimilação dos índios. Também já se descreveu, como o protesto de Horta Barbosa contra o "parágrafo do extermínio" de von Ihering, foi recebido e amplificado, cinco dias depois, pelo Centro de Ciências, Letras e Artes de Campinas, do qual era orador oficial em 1909. Os protestos de Tito de Lemos e Vicente Melillo, semelhantemente inspirados, originaram-se nas sessões ordinárias daquela mesma sociedade, e, finalmente, Hermann von Ihering usou o salão do poderoso Instituto Histórico e Geográfico de São Paulo para apresentar slia resposta às acusações feitas por Alberto Fric, no mês anterior, no Congresso de Americanistas, em Viena.

\section{A posição da Igreja Positivista.}

Os argumentos contra o extermínio dos índios, apresentados pelos positivistas Sílvjo de Almeida e Luís Bueno Horta Barbosa, levaram a Igreja Positivista para o debate indígena de 1908-1910, de maneira quase idêntica como se tinha dado a participação do Museu Paulista, do Centro de Ciências e do Instituto Histórico de São Paulo. O ataque de Horta Barbosa a von thering, embora tivesse aparecido primeiro na imprensa local de Campinas, foi publicado mais ou menos três semanas depois no órgão oficial da Igreja Positivista (1). Pouc) tempo depois foi reimpresso, em sua forma original, na edição de 11 de novembro do Jornal do Commercio, sob o subtítulo "Em defesa dos indígenas brasileiros". Junto com êste protesto foi publicada uma carta, escrita em 3 de novembro por R. Teixeira Mendes, dirigente da Igreja Positivista, ao cidadão Afonso Augusto Moreira Pena, Presidente do Brasil. Repetindo a declaração de von Ihering, de acôrdo com a citação de Horta Barbosa, Teixeira Mendes avisou o chefe da nação de que

"Em São Paulo, um cientista, o Dr. H. Ihering, na 'Revista do Museu Paulista', vol. VII, pág. 215, ousa pregar impunemente o exterminio dos selvagens brasileiros, isto é, ousa pregar o assassinato de milhares de homens inocentes!" (2).

Com a publicação do protesto de Horta Barbosa pela imprensa da Igreja Positivista e com a reprodução subseqüente

(1). - Igreja e Apostolado Positivista do Brasil, n.0 271 (novembro de 1908), págs. 9-14.

(2). - Jornal do Commercia (Rio de Janeiro), 11 de novembro de 1908, pág. 12, colunas 1-2. 
no Jornal do Commercio, por R. Teixeira Mendes, esta acompanhada pela sua própria mensagem ao Presidente da República, tornou-se claro que os ataques de Sílvio de Almeida e Horta Barbosa contra as teorias de ciência fria, mantidas por von Ihering a respeito do extermínio dos índios, representavam mais do que as opiniões pessoais de dois ardentes positivistas; êles expressavam, com igual certeza, a posição oficial da Igreja Positivista.

Von Thering não se deu o trabalho de responder pùblicamente a êste primeiro ataque de Teixeira Mendes. Mesmo, a referência a sua pessoa pode ter-lhe escapado, já que estava escondida na página 12. de um jornal do Rio, junto com outro material, sob um título geral que não sugeria tratar-se do extermínio dos índios. No entanto, o próximo ataque formal, publicado nos jornais da Capital do país, chamou sua atenção imediata e causou-lhe maior perturbação e fúria do que qualquer dos que se originaram em seu próprio Estado. Pois, agora a agressão não provinha da pena de um publicista, de um professor ou de um filósofo, nem de um discurso apresentado num centro cultural, mas direta e oficialmente dos encarregados de um museu rival, do Museu Nacional do Rio de Janeiro.

\section{O Museu Nacional e o debate.}

As relações entre os museus do Rio de Janeiro e de São Paulo nunca tinham sido cordiais. A rivalidade e o esfriamento de relações datavam de 1895, quando von Ihering, como diretor do recém-fundado Museu Paulista, situado nos limites da cidade, fêz um discurso durante a cerimônia inaugural, no qual desprezou o Museu Nacional de um modo que difìcilmente podia ser considerado acidental. Um outro Estado - disse êle - tinha criado "um museu com pessoal científico e sôbre bases mais amplas" do que as do novo Museu Paulista. Aquêle Estado - - acrescentou - era o do Pará, e o Museu referido estava sob a "direção competente" do seu bom amigo, Dr. Goeldi (3). A única interpretação possível das palivvras de von Thering era que o cientista alemão já considerava ser o museu recém-organizado superior ao Museu Nacional, tanto em instalações como em pessoal, apesar dêste ter sido fundado em 1886 e de ter acumulado suas coleções e treinado seus funcionários durante nove anos.

(3). - Revista do Museu Paulista, vol. I (São Paulo, 1895), pág. 24. 
As observações de von Ihering, publicadas na Revista do Museu Paulista, de 1895, chegaram ao Museu Nacional justamente no momento em que sua publicação ia ser impressa. Juão Batista de Lacerda, seu diretor desde a fundação, ofendeu-se profundamente com a atitude e as palavras insultantes di cientista alemão. Numa resposta mordaz aos comentários de von Ihering, Lacerda escreveu na revista do seu próprio museu que o diretor do Museu Paulista, no seu discurso inaugural, deve ter tido

“...em vista insuflar o amor próprio dos paulistas e recomendar aos poderes do Estado os seus incomparáveis serviços" (4).

Lacerda admitiu não ter tido ainda a "felicidade de ultrapassar os umbrais do Monumento do Ipiranga, para admirar a organização, sôbre bases científicas, do Museu Paulista", à qual von Ihering se tinha referido. Com sarcasmo amargo acrescentou que esperava poder "gozar dessa ventura" antes de morrer (5). (Mesmo em 1895, São Paulo estava a apenas oito ou dez horas de trem do Rio de Janeiro).

Voltando ao ano de 1908, treze anos após a sua primeira discussão, von Ihering e Batista de Lacerda estavam ainda dirigindo seus respectivos museus. Pode-se admitir que ainda a rivalidade estava na base de suas relações mútuas. Mas Lacerda não era o único componente do pessoal do Museu Nacional de quem von Ihering guardava sentimentos de fricção passada. O Professor Domingos Sérgio de Carvalho, diretor da secção de Antropologia do Museu Nacional desde 1898, tinha, segundo von Thering, tentado interferir na concessão do Grande Prêmio, durante a Exposição Nacional, que teve lugar no Rio de Janeiro, durante os últimos meses. Este prêmio foi conferido aos grupos de índios, expostos pelo $\mathrm{Mu}-$ seu Paulista, os quais em grande parte representavam as idéias e os esforços do seu diligente diretor, Hermann von Ihering (6).

Vale a pena dizer alguma coisa sôbre êste antropólogo, Sérgio de Carvalho, pois, como conselheiro técnico do Minis-

(4). - Batista de Lacerda, "Ao Sr. Dr. von Ihering, Diretor do Museu Paulista ", in Revista do Museu Nacional, vol. I (1896), pág. XIX. Esta publicação de 1896 vem citada, às vêzes, como o vol. IX dos Arquivos do Museu Nacional.

(5). - Ibidem, pág. XX.

(6). - Uma đescrição desta exposiçāo e uma breve menção do prêmio recebido foram publicadas na Revista do Museu Paulista, vol. vili (1911), págs. 5-6. V. págs. 115 para a referência dé von Ihering à tentativa de interferir com a concessão daquele prêmio ao Museu Paulista. 
tro da Agricultura, em 1910, estava êle destinado a assumir um papel importante no desenvolvimento de uma política governamental em relação aos índios. Embora dezesseis anos mais moço que Hermann von Ihering, Carvalho pertencia ao Müseu Nacional desde 1895, o ano em que o Museu Paulista foi inaugurado. Treinado como engenheiro agrônomo, durante muitos anos foi êle diretor da Sociedade Nacional de Agricultura. Já antes de 1908 tinha êle mostrado um interêsse pessoal no bemestar dos índios e provàvelmente mais por causa dêsse interêsse do que por causa de uma possível antipatia em relação a vcn Thering, êle levou o Museu Nacional a tomar parte no debate sôbre o extermínio dos índios.

Na 381.a sessão da Congregação do Museu Nacional, em 25 de novembro de 1908, Sérgio de Carvalho leu a "declaração do extermínio" de von Thering, de notoriedade cada vez maior, para os seus colegas. Acrescentou também o parâgrafo seguinte, citado aqui em seguida, porque se une ao anterior. Sem dúvida, esta outra passagem tinha influenciado aquêles cujos ataques a von Ihering já foram resumidos, embora até êste momento nenhum dos seus adversários se tivesse referido especificamente a ela. As palavras do cientista alemão, como foram lidas por Carvalho, em 25 de novembro, eram as seguintes:

"A conversão dos índios não tem dado resultado satisfatório; aquêles índios que se uniram aos portuguêses imigrados, só deixaram uma influência maléfica nos hábitos da população rural. E' minha convicção de que é devido essencialmente a essas circunstâncias, que o Estado de São Paulo é obrigado a introduzir milhares de imigrantes, pois que não se pode contar, de modo eficaz e seguro, com os serviços dessa população indígena, para os trabalhos que a lavoura exige" (7).

Sérgio de Carvalho admitiu que não era comum para uma instituição como o Museu Nacional envolver-se em questões que não eram estritamente científicas, mas êle sentia que não podia ficar calado, enquanto que o diretor de um museu estadual estava "chegando a aconselhar" o extermínio dos ín=dios. A palestra de Carvalho não aparece verbatim na ata desta sessão, a qual apenas resume suas palavras e indica que êle falou com algum desenvolvimento sôbre a inexatidão das alegações de von Thering referentes à inutilidade dos índios

(7). - "Ata da 381a. sessão da Congregação do Museu Nacional, efetuada em 25 de novembro de 1908", in Registro das Atas das Sessões da Congregação (Ms. existente no Museu Nacional). Carvalho leu a passagem c1. tada corretamente da Revista do Museu Paulista, vol. VII (1907), pág. 215. 
como trabalhadores. Além disso, o antropólogo criticou acerbamente a prática seguida em São Paulo, de gastar verbas governamentais em planos de imigração, ao passo que não se fazia nada para instruir os índios em trabalhos produtivos. Em conclusão, anunciou que, sòzinho ou com o apôio de seus colegas, pretendia preparar um protesto formal às declarações de von Ihering. Imediatamente após o ataque de Carvalho contra seu colega do Museu Paulista e sua decisão de protestar formalmente contra as teorias de von Ihering sôbre o extermínio dos índios, Amaro F. das Neves Armond, diretor da secção de: Botânica, propôs que o protesto sugerido por Carvalho fôsse publicado na revista do Museu. Por ora, o mesmo Neves Armond pedia que o Secretário incluisse na Ata o fato dêle sentir profundamente a orientação científica do Dr. von Ihering, a qual o levou a "aconselhar o expediente cruel de exterminar os indígenas brasileiros". Hildebrando Teixeira Mendes (não deve ser confundido com Raimundo Teixeira Mendes dia Igreja Positivista) sugeriu que o protesto proposto fôsse preparado pessoalmente por Sérgio de Carvalho e publicado tanto no Jornal do Commercio, como nos Arquivos do Museu Nacionl. Além disso, sugeriu êle a convocação de uma sessão especial, em futuro próximo, para ouvir e aprovar o protesto de Carvalho. De acôrdo com aquela sugestão, em 3 de dezembro, um breve aviso, distribuído a seis cientistas do Museu Nacional, cujos nomes aí aparecem, notificou-os da leitura, à uma hora da tarde do dia seguinte, de um protesto contra "...a bárbara medida de extermínio dos indígenas brasileiros, aconselhada pelo Diretor do Museu de São Paulo" (8) .

A sessão especial de 4 de dezembro, com o comparecimento de nove funcionários, foi declarada aberta com atraso, às duas horas, pelo diretor do museu, Batista de Lacerda. As suas observações iniciais, seguiram-se alguns comentários gerais de Sérgio de Carvalho, como introdução ao protesto que ia submeter à aprovação de seus colegas.

O interêsse especial e a simpatia que Carvalho dedicava aos índios aparecem claramente no seu ataque cuidadosamente formulado contra a declaração de von Ihering sôbre o extermínio. Afirmou que os índios eram os verdadeiros filhos da terra e que êles tinham recebido os primeiros colonizadores com confiança e amabilidade. Seguramente, de acôrdo com o

(8). - Ms. existente no Museu Naclonal (Pasta 51, Documento n.0 234). Pela presença do diretor, do secretário e do autor do protesto, Sergio de Carvalko, o número dos participantes desta reunião la elevar-se a nove. 
raciocínio de Carvalho, os nativos, após tantos anos de sofrimento, agora tinham que considerar a civilização do branco como inferior à sua própria, julgando-à em têrmos de tratamento dispensado às raças mais fracas. A atual incompreensão $\mathrm{e}$ fricção nas relações entre brancos e índios não era - afirmou - antropólogo - culpa dos nativos, mas da geração atual de brasileiros; porque socorrem o imigrante com amplos privilégios legais, mas ignoram completamente as necessidades da população indígena.

$\mathrm{Na}$ opinião de Carvalho, as teorias expressas pelo cientista, natural da Alemanha, eram tanto anti-científicas como desu.manas; se a raça branca era superior à indígena, como era implícito do texto de von Ihering, então ela primava apenas pela sua ambição egoista e pelo seu desêjo sórdido de escravizar e governar pela fôrça. O índio, longe de representar um ser inferior, era, nas palavras de Carvalho:

“...em geral, inteligente, industrioso, com grande capacidade de trabalho, quando the cabe direção competente e desvelada" (9).

O título do trabalho lido por Carvalho ("Protesto formulado pela Congregação do Museu Nacional contra a idéia de extermínio dos indígenas brasileiros sugerida pelo Diretor do Mustu de São Paulo") indica que o autor e seu grupo não eram menos reticentes que Almeida, Horta Barbosa, Tito de Lemos, Melillo e $\mathrm{R}$. Teixeira Mendes em atribuir às palavras de von Ihering motivos e intenções da pior espécie possível. No comêço do protesto, Carvalho atribuia ao cientista alemão a "idéia... de votar-se ao extermínio milhares de sêres humanos, filhos genuínos dêste país". No parágrafo seguinte êle se referiu ao

"...desvario com que se procura sancionar a crueldade que, de há muito, se exerce contra os indígenas brasileiros, e levá-la ao extremo de um morticínio impiedoso, praticado em nome da lei e dos interêsses nacionais" (10).

Não é de se admirar que von Ihering se ofendeu com êste protesto. Ele tinha aprendido, nas últimas semanas, a esperar

\footnotetext{
(9). - "Protesto formulado pela Congregação do Museu Nacional contra a idéla de extermínio dos indígenas irasileiros, sugerida pelo Diretor do Museu de Săo Paulo". Ms. com a calígrafla de Sérglo de Carvalho existente no Museu Nacional (Pasta 51, Documento n.0 236). Este documento está assinado por todos que estiveram presentes à sessão especial, com exceção do secretário que o lavrou.

(10). - "Protesto formulado..." (Doc. n.0 236).
} 


\section{$-420-$}

um ataque como êste de filósofos e religiosos, mas não de um grupo de cientistas, seus colegas. O protesto de Carvalho era para von Ihering a gôta que fêz transbordar o cálice e significava que nem mesmo nos cientistas podia êle confiar para apôio de suas convicções científicas. Em lugar do apôio que podia esperar da congregação do Museu Nacional, von Ihering encontrou; nas palavras finais do protesto de Carvalho, um provocador desafio:

"...e agora que o diretor de um estabelecimento científico nacional, servindo-se do prestígio da instituição que representa, procura acoroçoar tais violências, por dilatar os dominios da Colonização, cumpre à Congregação do Museu Nacional, firmar o presente protesto, certa, entretanto, de que os poderes públicos não permitirão a vitória dessa idéia criminosa" (11).

O protesto foi unânimemente aprovado e assinado pelos colegas de Carvalho. Não se sugeriram alterações. $\mathrm{Na}$ discussão que se seguiu à leitura, Hildebrando Teixeira Mendes (um engenheiro de minas) declarou que:

"...um funcionário que aconselha semelhante medida, sôbre desumana, criminosa, revela de par com uma audácia inacreditável, a maior falta de critério, merecendo, no seu entender, ser demitido a bem do serviço. público, visto ter-se tornado passivel das penas do Código Criminal" (12).

Em 6 de dezembro, apenas dois dias após a leitura e aprovação do protesto de Carvalho no Museu Nacional, o mesmo foi levado à atenção do público leitor da capital do país, pelo Jornal do Commercio, como protesto contra as opiniōes do

"...Sr. Dr. von Thering (sic) que, como meio de civilização das regiões incultas do Brasil, aconselha o extermínio dos indígenas, no vol. VII da revista..." (13).

Com. a publicação do protesto de Carvalho, o assunto do extermínio dos índios tornou-se uma questão de interêsse geral na capital do país. O Museu Nacional recebeu cartas de

\footnotetext{
(11). - Ibidem. Este protesto pode ser encontrado, corretamente reproduzido, no Jornal do Commercio de 6 de dezembro de 1908, pág. 4, col. 4 e nos Arquivos do Museu Nacional, vol. XV (1909), págs. 256 e seg.

(12). - "Ata da 382a. sessão da Congregação do Museu Nacional, realizada em 4 de dezembro de 1908 , em virtude de convocação extraordinária". Registro das Atas (Ms.). Esta citação fol tirada das Atas da sessão e possivelmente não constitui uma repetição exata das palavras do engenheiro.

(13). - Jornal do Commercio de 6 de dezembro de 1908, pág. 4, col. 4.
} 
congratulações e apôio, tanto de indivíduos como de associaçôes. A primeira, datada de 8 de dezembro, veio do Centro Republicano Conservador de Niterói, do outro lado da baía. Sua mensagem era breve mas confortadora para a Congregação do Museu Nacional, que provàvelmente estava curiosa em saber, como sua posição referente à questão indígena seria recebida por outros cientistas e pelo público em geral. $\mathrm{O}$ texto era o seguinte:

"Ả Digna e patriótica Congregação do Museu Nacional levamos o nosso apôio ao protesto firmado contra o extermínio dos indigenas, certos de que os poderes públicos não permitirão a vitória dessa idéia criminosa" (14).

Também R. Teixeira Mendes, da Igreja Positivista, não tardava a exprimir sua aprovação às medidas tomadas pelo Museu Nacional. Num longo artigo publicado na edição de $\mathbf{9}$ de dezembro do Jornal do Commercio, primeiro fêz citações do protesto de Horta Barbosa, do mês anterior. Depois dessa introdução ao assunto, Teixeira Mendes repetiu a notícia daquele jornal sôbre o ataque do Museu a von Ihering. Em conclusão, junto com alguns comentários próprios, Teixeira Mendes citou integralmente o último protesto. Evidentemente êle queria ter certeza de que a posição humanitária, assumida pelo Museu Nacional com referência à questão indígena, não escaparia à atenção dos habitantes do Rio de Janeiro.

\section{A Associação de Proteção e Auxílio aos Selvícolas do Brasil e a Declaração de von Ihering.}

No mesmo dia, em 9 de dezembro, antes que von Ihering tivesse possibilidade de responder ao ataque do Museu, um dos protestos mais poderosos até agora levantados contra suas opiniões impopulares foi lido durante uma sessão regular da Associação de Proteção e Auxílio aos Selvícolas do Brasil. A estranha história dessa Associação será apresentada mais tarde neste trabalho. Por ora, a Associação, em si, é menos importante do que os argumentos levantados por sua fundadora, em apôio ao protesto do Museu Nacional e em refutação da declaração de von Ihering.

A fôrça dêste novo ataque contra o cientista do Museu Paulista originava-se no fato de que a autora tinha passado

(14). - Ms. existent $e^{-}$no Museu Nacional (Pasta 51, Documento n.o 237). Esta mensagem fol publicada posteriormente no Jornal do Commercio de 15 de dezembro de 1908, pág. 4, col. 2. 
cinco anos, de 1896 a 1901, nas aldeias de dezessete tribos dos vales dos rios Araguaia e Tocantins, nas regiōes mais isoladas do Estado de Goiás. A oradora era uma autoridade sôbre os costumes e as potencialidades do índio selvagem. Esta era uma voz que não podia ser silenciada pelo pêso de evidências adversas do passado, nem por previsões científicas sôbre a exterminação inevitável.

Este protesto é de um interêsse especial por ser proveniente de uma mulher, conhecida entre os índios, tão amados por ela, como "Mamãe" ou, mais freqüentemente, sob o nome indígena "Oassy-Zatiré". Seu nome verdadeiro era Leolinda de Figueiredo Daltro. Em 1896, jovem ainda, tinha deixado um lugar de professôra no Rio de Janeiro e, com seu filho, entranhara-se nas matas de Goiás para educar os índios daquela região e protegê-los da exploração. Agora, doze anos depois, ao tempo do seu protesto contra as teorias de von Ihering, Leolinda Daltro era uma figura bem conhecida no Rio de Janeiro, não apenas por causa da publicidade dada a suas experiências passadas em Goiás, mas também pelo fato dela associar-se quase diàriamente, em público, com um grupo de cinco ou seis índios de puro sangue, os quais tinha trazido para a Capital e instruído, de acôrdo com os costumes e a boa educação da vida metropolitana do século XX.

$O$ protesto formal lido por Leolinda Daltro perante a Associação de Proteção, no Rio, foi tão incisivo em seu aspecto pessoal em relação a von Ihering como qualquer dos ataques precedentes. Em tom mordaz e sarcástico a oradora aludiu ao racismo germânico:

\footnotetext{
"Certo, o Dr. von Thering não é brasileiro; e se o é, a germanização do seu nome faz acreditar no perigo amarelo - que tantos sobressaltos causa à sonhada preponderância e eternização da raça alemã".
}

$\mathrm{Na}$ opinião da Sra. Daltro, o "conselho do extermínio de mais de um milhão de brasileiros", advogado pelo cientista alemão, era uma idéia audaciosa e criminosa que violava todos os preceitos de comportamento moral. Além disso - acrescentou - tal conselho ofendia desvergonhadamente os princípios humanitários endossados na Conferência da Paz de Haia, em 1907. Como estava distante a ciência materialista de Hermann von Ihering - declarou - da política nobre e fidalga de Rui Barbosa.

Como Carvalho e seus colegas do Museu Nacional, Leolinda Daltro investiu contra o menosprezo que von Ihering dedi- 
cava ao caráter do índio e à sua habilidade de trabalhar, baseando-se no desacôrdo de tais opiniōes com os resultados mais recentes da pesquisa antropológica. Também, baseando-se na experiência de seus anos entre dezessete tribos de índios, falou eloqüentemente do bem inerente e do valor potencial, que êstes povos primitivos representavam para o Brasil:

"Confesso que jamais vi em nenhuma delas um indio, 'em estado selvagem, que fôsse assassino, ladrão, ébrio ou sedutor. Inteligentes, amorosos, gratos, obedientes e sedentos de instrução, amam a justiça e o trabalho" (15).

Sentida e nostàlgicamente, a oradora lembrou então a maneira pela qual seus amigos índios cultivavam suas roças com bastões e lascas de pedra, apenas para perder suas colheitas, seus campos, sua liberdade - e mesmo suas vidas - por causa da cobiça insaciável do branco. Baseada em sua experiência direta, ela confirmou o ponto de vista já externado em protestos anteriores, que os civilizados e não os indómitos nativos eram os maiores responsáveis pelo presente estado de guerra entre brancos e indígenas. Seus sentimentos encontram-se corajosamente expressos na seguinte passagem:

"Feras humanas, os chamam! $\mathrm{E}$ o são na verdade, mas só quando os que se dizem civilizados lhes roubam os cereais que plantam, os animais que criam, ou os enxotam a ferro e a fogo das terras que regam com o suor do rosto e lhes tomam as mulheres e filhas que são tôda a sua felicidade. Em regra, os índios nunca se insurgem e quando rarissimamente o fazem é sempre a contragôsto, com dolorosos sacrifícios e como natural e necessária reação provocada sempre pela ambição, pela libidinagem e pelo autoritarismo dos pseudo-civilizados que ainda não perderam a vergonhosa mania de escravizar entes humanos" (16).

Leolinda Daltro estava firmemente convencida que os índios da floresta desejavam os benefícios da civilização, apesar do mêdo que tinham dos brancos. A única coisa que precisavam e pediam - continuou - era instrução, administrada por pessoas que dessem um exemplo moral pela sua conduta. A oradora assegurou aos que a ouviam a certeza de resultados benéficos, caso fôsse levado adiante um programa extenso de instrução dos índios. Seus próprios amigos indígenas no Rio de Janeiro, trazidos è educados por ela pessoalmente, constituiam

(15). - Leolinda Daltro, Da Catechese dos Indios no Brasil: 1896-1911 (Rlo de Janelro, 1920), pág. 624.

(16). - Ibldem, págs. 624-625. 
um exemplo vivo - afirmou - dos benefícios que pudessem ser obtidos de tal programa, pois todos eram "cidadãos eleitores.... artistas, sem nenhum vício, verdadeiros homens de bem, inexcediveis em sentimentos generosos e delicados, no brio e ná dignidade pessoal" (17).

Terminando seu próprio protesto contra a "doutrina" von Ihering, Leolinda Daltro pediu que um outro protesto fôsse apresentado à Asşociação e incluído na Ata da sessão - êste preparado e assinado pelos cinco índios, aos quais se tinha referido. Este segundo ataque deve ter impressionado von Ihering de um modo especial, pois numa revisão amarga dos fatos do debate indígena, escrita em 1911, êle o indicou como um dos memoráveis vexames da campanha encetada contra êle (18). Sem dúvida, êste protesto contra o extermínio dos nativos, formulado e legivelmente assinado por um grupo de írdios antes completamente incultos, foi sentido quase como um choque pelo cientista alemão, já tão atacado. As circuns: tâncias especiais, sob as quais aparece êste documento pouco conhecido, justificam sua reprodução integral neste lugar:

"Os indios brasileiros abaixo assinados, já incorporados à civilização, e representantes nesta Capital das tribos guaranis, guajajaras, xerentes e caraós, protestam, surprêsos e pasmos, contra a opinião do Dr. von Thering que, em pleno século $X X$, entende ser uma necessidade imposta pela civilização o extermínio de todos os nossos irmãos das selvas e, portanto, de tôda raça genuinamente brasileira. Ao ilustre diretor do Museu de São Paulo podemos garantir que nas nossas incultas tribos nenhum selvagem aprovará uma carnificina de entes humanos, a não ser na sagrada defesa dos direitos que nos dá a natureza que são, sem nenhuma diferença, os mesmos que ela confere aos homens de muita ciência, mas de nenhum sentimento humanitário. A ciência do Dr. von Ihering opomos a moral de todo mundo civilizado em pleno antagonismo cọm sua opinião, que só representa uma extravagante aberração do espirito humano. $\mathbf{E}$ tanto basta para êste necessário protesto" (19).

Os protestos apresentados por Leolinda Daltro e seus alunos foram calorosamente aplaudidos e unânimemente aprovados por todos os sócios presentes. Mais tarde serão relatadas outras atividades da Associação de Proteção e Auxílio aos Selvicolas do Brasil.

(17). - Ibidem, pág. 625.

(18). - Revista do Museu Paulistä, vol. VIIİ (1911), pág. 114.

(19). - Daltro, Da Catechese..., pág. 626. 
A maneira pela qual os artigos de $R$. Teixeirä Mendes no Jornal do Commercio e o protesto da Congregação do Museu Nacional tinham alertado a Capital do país a respeito do extermínio dos índios, não passou desäpercebida no Estado de São Paulo, onde a controvérsia tinha começado. No Centro de Ciências de Campinas, Tito de Lemos (um dos primeiros atacantes da declaração de von Ihering) levantou-se, durante a sesșão ordinária de 12 de dezembro, para informar seus consócios das medidas tomadas pelos cientistas do Museu Nacional. Lemos sugeriu que se informasse o museu do Rio da denúncia clara e pública que o Centro tinha feito em relação à "subversiva doutrina pregada pelo Diretor do Museu de São Paulo, do massacre dos indígenas brasileiros" e de sua disposição em levar avante um movimento de âmbito nacional, apoiado nas garantias constitucionais da igualdade entre os cidadãos, para proteger a vida dos infelizes índios brasileiros que tinham sido o "sport" (sic) em atos de agressão criminal (20). Embora na A ta desta sessão não aparecesse claramente quem deveria iniciar esta ação conjunta em prol dos índios, há pelo menos evidência de que o orador estava certo que tal movimento iria desenvolver-se logo.

Mensagens como esta, de congratulações e apôio de uma scciedade para a outra, eram o passo inicial num programa dêsse tipo. Elas constituiam uma expressão de adesão a uma causa comum e uma afirmação de solidariedade para qualquer medida a ser adotada. Para estas sociedades, assim como para indivíduos, a fôrça numérica era um fator importante na determinação do grau de valentia a ser empregado para a solução efetiva do problema indígena. Mesmo ao pequeno Centro Republicano Conservador de Niterói deu-se acolhida cordial por meio de uma carta de agradecimento do Museu Nacional, pelo seu

“...patriótico e espontâneo apôio ao protẹsto firmado.. contra a cruel medida de extermínio dos indígenas brasileiros, aconselhada pelo Diretor do Museu de São Paulo" (21).

\section{A resposta de von Ihering ao Museu Nacional.}

Desde 11 de novembro, quando R. Teixeira Mendes apresentou pela primeira vez a declaração de von Ihering sôbre o

\footnotetext{
(20). - Ata da 313a. sessão ordinária in Revista do Centro de Ciências, Letras e Artes, n. ${ }^{\circ}$ 31. (junho de 1913), pág. 77.

21). - Cópias dos ofícios: 1907-1910 (Ms. existente no Museu Nacional), pág. 229 (Documento n:० 131, de 12 de dezembro de 1908).
} 
extermínio dos indígenas aos habitantes do Rio de Janeiro, através das páginas do Jornal do Commercio, notava-se na Capital do país uma curiosidade crescente quanto às verdadeiras intenções do cientista de origem alemã. Desejava êle de fato o extermínio de muitos ou de todos os índios do Brasil, ou estava êle sendo difamado e mal interpretado pelos seus numercsos inimigos? Sòmente em meados de dezembro esta curiosidade foi satisfeita, quando o Jornal do Commercio imprimiu a resposta de von Ihering ao protesto assinado pela Congregação do Museu Nacional.

Novamente o cientista perdeu uma oportunidade para refutar a opinião agora já bem difundida de que êle tolerava ou recomendava o extermínio dos índios em larga escala. Ele poderia ter diminuído a pressão contra sua pessoa pelo uso de uma linguagem conciliatória ou por uma explanação clara de seus motivos e intenções. No entanto, sua tentativa para explicar o verdadeiro significado de sua declaração primitiva sôbre o extermínio foi não apenas superficial mas também irritante em seu tom argumentativo, como aparece nas seguintes palavras:

"Em primeiro lugar é preciso notar que nunca falei em 'exterminio de indios', mas que fiz ver a diferença que há entre os indígenas semi-civilizados que sujeitam às nossas autoridades e aquêles índios ferozes, que são absolutamente refratários a qualquer ensaio de sujeitá-los ao nosso regime e que vivem em guerra cruel e contínua com a população vizinha" (22).

A única outra tentativa de von Ihering para dissociar seu nome da idéia do extermínio dos índios em larga escala, era uma passagem mais adiante no artigo, a qual deixava subentender que o ataque à sua pessoa era apenas o resultado de seus comentários anteriores sôbre o extermínio dos coroados, índios arredios do Brasil meridional.

Von Ihering, embora não parecesse ainda sinceramente desejar uma reconciliação com os seus adversários, estava não obstante interessado em não continuar êste debate unilateral. A única maneira, pela qual podia retirar-se de uma controvérsia cada vez mais acalorada, era o desvio do ataque de sua pessoa para algum outro culpado. Isto começou êle a fazer muito sabidamente, apresentando aos seus críticos uma lista de três motivos, os quais indicava como diretamente respon-

22). - Esta citação e as seguintes da resposta de von Ihering foram tiradas de Hermann von Ihering, "Exterminio dos indigenas ou dos sertanejos?", in Jornal do Commercio de 15 de dezembro de 1908, pág. 2. 
sáveis pela prática infeliz do exterminio dos índios. Em primeiro lugar, nesta lista, estava a inexorável lei da sobrevivência do mais apto; em segundo, a prática da caça aos índios, predominante no Estado de São Paulo, onde (na opinião de von Ihering) os próprios brasileiros ultrapassavam de longe os colonos alemães nos Estados meridionais em seus massacres impiedosos dos índios hostis. Em terceiro lugar de sua lista estava a falha do Govêrno na proteção aos colonos contra a agressão indigena e, dêste modo, na manutenção da paz entre as facções em guerra.

A convicção de von Ihering de que era inevitável o extr.rmínio dos índios estava implícita na pergunta formulada na sua refutação mais recente: "Extermínio dos índios ou dos sertanejos?" O cientista submeteu o assunto à escôlha dos seus leitores da seguinte maneira:

"Existindo entre êstes e os pioneiros da cultura moderna do Brasil uma luta encarniçada, pode-se, com o Museu Nacional, tomar o partido dos indigenas, sacrificando os sertanejos e colonos, ou exigir conosco a defesa dêsses últimos, aprovando assim o exterminio dos selvagens".

Aparentemente não havia dúvida na mente de von Ihering de que, uma vez que os brasileiros tivessem compreendido a situação nestes têrmos, êles aceitariam o extermínio dos indios, enquanto fôsse necessário, para assegurar o avanço seguro dos colonos para o interior. "Deixemos agora a questáo dos coroados, cuja sorte está fatalmente decidida...", escreveu êle em seguida; não lamentando de nenhuma forma a necessidade aparente de sacrificar o elemento indígena na vida nacional. A previsão de von thering sôbre a extinção final dos índios brasileiros está formulada de tal forma que parecia mais uma rejeição desafiadora da sentimentalidade de seus adversários do que uma profecia objetiva, cientificamente fundamentada. Referindo-se ainda aos "índios ferozes", escreveu:

"O número dêstes últimos diminui em proporção rápida; o seu exterminio realiza-se sem interrupção. E' irrelevante se fica vencedora a opinião do Museu Nacional ou a do Museu Paulista, visto que ambos nenhuma influência têm para impedir o que se realiza com a regularidade própria de uma lei natural".

Além disso, na opinião de von Ihering, tal extermínio se efetuava tanto pelo conflito com brasileiros como com colonos alemães. Contrariando agora suas declarações anteriores, de 
2n de outubro, o cientista alegou que também São Paulo tinha stu modo de fazer caça aos índios. Na parte ocidental do Estr.do, onde os colonos se constituiam de elementos nacionais em vez de imigrantes alemães - continuou êle explicando - as expedições mandadas contra os indígenas eram compostas de grandes quantidades de índios guaranis, obrigados a tal serviço, e os bugreiros, na sua maior parte, eram criminosos. Contràriamente ao resultado das caças, quando realizadas na área dc colonização alemã em Santa Catarina - declarou von Ihering - as expedições em São Paulo, quando coroadas de êxito, tinham como conseqüência a matança dos homens, das mulheres e das crianças, encontrados nas aldeias indígenas que fôssem atacadas.

Nos seus esforços de dirigir a atenção dos brasileiros para - extermínio e o mau tratamento dos indígenas nas partes do país que não estavam ocupadas por alemães, isto é, certas regiões dos Estados meridionais, von Thering entrou em detalhes sôbre o pleito infeliz dos nativos semi-civilizados de São Paulo. Explicou que naquele Estado os índios mansos eram

“...dizimados por febres malígnas e doenças epidêmicas, explorados por falsos amigos, empreiteiros, fazendeiros e, às vêzes, padreș ou frades...".

Freqüentemente - continuou o articulista - os índios eram forçados a trabalhar sem retribuição. Quando, ocasionalmente recebiam terras próprias, não podiam confiar no apôio das autoridades locais para manter seus direitos legais sôbre as mesmas.

$O$ artigo de von Thering continua com uma queixa sôbre - modo estúpido pelo qual seus críticos foram levados a criticá-lo em vez de investir contra o Govêrno que era fundamentalmente responsável pela desgraça dos índios. A política oficial em relação aos índios - alegou - estava desesperadamente indefinida, e tudo que fazia parte do tratamento dos indígenas estava num estado de completa anarquia. Ainda segundo von Ihering, os representantes da lei e da ordem não faziam diferença entre o assassinato de índios mansos $\mathrm{e}$ a matança de coroados bravios. A série de protestos, na opinião do articulista, não devia dirigir-se contra êle, mas contra a maneira oficial de tratar os índios. Lembrou aos seus leitores que Alberto Fric, no Congresso Americanista de Viena, já tinha cnamado a atenção dos europeus para a falta do gcvêrno brasileiro em assumir suas responsabilidades. Von Ihering advertiu que a negligência governamental nos distúr- 
bios indígenas poderia causar uma onda de discussões desfavoráveis no estrangeiro, o que seria mau, considerando que alguns países europeus já tinham começado a legislar contra a emigração para o Brasil - ou estavam planejando nesse sentido - em vista do perigo de ataques indígenas às colônias fronteiriças. O cientista assegurou aos seus leitores que o Brasil precisava urgentemente de colonizadores mas não podia esperar atraí-los em número suficiente, se não aceitasse a responsabilidade de proteger suas vidas e os frutos de seu trabalho.

$\mathrm{Na}$ América do Norte, no Chile e na Argentina fortes militares protegiam os colonos nas fronteiras mais expostas, e uma polícia especial - continuou von Ihering - tinha resclvido o problema indígena em outros países e poderia fazer o mesmo no Brasil. Tal instituição não apenas pouparia aos colonos o dever árduo e perigoso de se vingar dos ataques dos indios, mas também salvaria mulheres e crianças indígenas do massacre empreendido pelos bugreiros e colonos do Oeste do Estado de São Paulo. Apenas pela ação governamental, em forma de ajuda militar aos colonos, poder-se-ia pôr um paradeiro à guerra brutal entre colonos e índios.

A citação seguinte é especialmente significativa. Ela provàvelmente se aproxima mais da revelação das intenções do cientista em relação à questão indigena do que qualquer outra passagem nesta refutação ou nas suas duas declarações públicas anteriores:

“... Não há página mais negra na atual civilização do Brasil do que esta guerra cruel entre indios e sertanejos, e de modo algum gostaria chamar a atenção às barbaridades nela cometidas. Tudo isto muda de feição desde o momento em que a defesa do sertanejo fica entregue a corpos policiais especiais".

Aqui, em sua terceira e última discussão pública do tema do extermínio, von Ihering admitiu que não sentia prazer em chamar a atenção para as barbaridades da guerra indígena. Não obstante, contràriamente aos cientistas alemães no Congresso Americanista de Viena, que tinham procurado silenciar a história do extermínio dos índios do Brasil, von Ihering tinha citado passagens dos relatórios chocantemente detalhados de Fric sôbre os métodos dos bugreiros de massacrar suas vítimas indígenas. A êstes relatórios êle tinha acrescentado descrições vivas de caça aos índios, tal como foram impressas em jornais alemães. E, como se isto não fôsse suficiente, o cien- 
tista tinha passado a apresentar sua própria versão das atividades dos bugreiros em Santa Catarina e tinha, finalmente, declarado que o extermínio dos índios através de ataques de surprêsa a aldeias indígenas estava mesmo mais sangüinário em São Paulo do que nos Estados meridionais.

Provàvelmente nem mesmo von Ihering poderia ter negado que tivesse escrito consistentemente duma maneira tal que despertava alarma e indignaação entre os brasilèiros sôbre o estado sério dos negócios indígenas. Com poucas exceções, seu tr atamento do assunto do extermínio dos índios tinha sido deliberadamente argumentativo e tinha servido apenas para provocar seus críticos a atacá-lo repetidamente. Se por indiferência calejada ou apelando sabidamente para a preocupação crescente dos brasileiros pelos direitos e o bem-estar pessoal dos índios como sêres humanos, von Ihering tinha, quase sòzinho, iluminado a chama da controvérsia sôbre a questão indigena e tinha-a atiçado num fogo poderoso. Seu êxito nesta atividade está em favor da teoria de que seu papel predominante neste comêço do debate não era o de uma vítima passiva de ataques pessoais, mas antes o de um instigador do argumento que, de acôrdo com a sua convicção, pudesse resultar em apôio militar do Govêrno para o movimento colonizador no Sul.

E' bem possível que o cientista tivesse desde o comêço reconhecido na exposição do extermínio dos índios, em Viena, e na reação violenta à descoberta por Sílvio de Almeida de sua própria declaração sôbre o assunto, uma oportunidade caída do céu para iniciar uma discussão acalorada em público, sôbre a guerra indígena que estava bloqueando o avanço econômico da nação e resultando em sofrimento e morte para os imigrantes pioneiros nos Estados meridionais. Também é possível que von Ihering tivesse inicialmente temido que esta discussão, como as anteriores sôbre o mesmo assunto, acabasse sem os resultados positivos que esperava, se os participantes evitassem as particularidades desagradáveis e incômodas das brutálidades praticadas tanto pelos índios como pelos colonos, em sua guerra violenta. Certamente, von Ihering não tinha evitado aquelas particularidades nem permitido aos seus atacantes de esquecê-las, mesmo se o tivessem desejado.

Nas palavras finais de sua resposta ao protesto do Museu Nacional, von Ihering formalmente se retirou da controvérsia que tinha criado e propagado. Declarou que não tomaria parte em novas discusões que se pudesem levantar sôbre o assunto do extermínio dos índios e assegurou aos seus leitores, em lin- 
guagem bastante áspera, que não havia afirmações científicas nc seu primitivo estudo antropológico sôbre os índios de São Paulo que necessitassem de modificação. $O$ fato de ter a monngrafia sido reeditada em inglês e traduzida, posteriormente, para o espanhol para ser usadas nas universidades argentinas, constituia uma prova - acrescentou - de que tinha atingido sua "única ambição... um perfeito conhecimento da etnologia do Brasil meridional".

Embora não pretendesse continuar o debate indígena, von Ihering dedicou aos seus críticos algumas últimas observaçōes irritantes que contribuiram para manter acesos os fogos da controvérsia durante os próximos meses. Em seu acostumado tom de argumentação, esclareceu que, embora pudesse haver diferença de opinião entre seu museu e o Museu Nacional quanto à parte que na guerra fronteiriça, índio ou sertanejo, deveria $s \in \mathrm{r}$ sacrificada ao extermínio, não podia haver diferença alguma de opinião em relação à noção idealista de que o indio selvagem pudesse beneficiar-se materialmente da civilização cu da economia do país. Num último e audacioso desafio às opiniões do Museu Nacional, von Ihering escreveu:

"E' simplesmente falso, quando o Sr. Sérgio de Carvalho diz do indígena que êste é 'em geral inteligente, industrioso, com grande capacidade para o trabalho, quando lhe cabe uma direção competente e desvelada.... Tudo que sabemos dos indigenas do Brasil meridional mostra claramente o contrário. Longe de ser um elemento de progresso e de trabalho, os indígenas catequizados são indolentes e indiferentes, e não fará a mínima diferença para a cultura e o progresso dêstes Estados se tais indígenas continuam a existir ou não... Só obrigados, só reduzidos mais ou menos ao estado de escravidão é que êstes selvagens são capazes de prestar reais serviços".

Repetindo a opinião de Couto de Magalhães de que o índio civilizado era "um homem depravado", von Ihering lembrou aos seus leitores que um general americano, não menos competente, de nome Custer, tinha defendido a opinião de que "bom índio unicamente é um índio morto".

Com esta apreciação negativa e pessimista da população indígena do país, Hermann von Ihering retirou-se da controvérsia, provocada pelas suas publicações. As idéias expressas por êle, porém, iriam continuar a revolver como pedras de amolar, soltando faiscas ocasionais, na medida em que lâminas nelas eram afiadas. 


\section{A resposta de Teixeira Mendes a von Ihering.}

O primeiro a responder às últimas declarações do cien= tista alemão foi R. Teixeira Mendes da Igreja Positivista. Chocado e intrigado pelas complicações da pergunta de von Ihering: "Extermínio dos índios ou dos sertanejos?", Teixeira Mendes respondeu num artigo, publicado no dia seguinte, 16 de dezembro, no Jornal do Commercio: "Em nome dos sentimentos humanos assim afrontados, e invocando a verdadeira ciência positiva, sacrificada aí a uma metafísica materialista cruel, nós respondemos: Nem o extermínio dos indígenas, nem o extcrmínio dos sertaniejos; a humanidade e a justiça com todos" (23). Com certeza - continuou - os princípios de justiça e humanidade não permitem a exterminação de homens, mulheres e crianças, simplesmente porque habitam terras cobiçadas por germânicos e latinos que já passaram do estágio primitivo para o moderno da civilização.

\section{A opinião da Sociedade Nacional de Agricultura.}

No dia 17 de dezembro de 1908, numa sessão da diretoria, a Sociedade aprovou uma moção, pela qual expressou sua confjança na capacidade do Govêrno para resolver o problema indígena, providenciando "instrução e educação cívica" em "colônias agrícolas" para aquêles índios "que forem vencidos pelo carinho e pela bondade dos representantes do Estado" (24). Assim, a Sociedade Nacional de Agricultura, um órgão técnico oficial do Ministério de Indústria, Viação e Obras Públicas, concordou com o Dr. von Ihering a respeito de uma questão fundamental: a que o próprio Govêrno Federal tinha o dever de tomar medidas positivas para parar a luta que se estava travando entre índios hostis e os invasores persistentes. O aparecimento da questão indígena na Sociedade Nacional de Agricultura completa esta crônica da introdução do debate indígena na imprensa e nas sociedades científicas da Capital do país. O Govêrno brasileiro, ou mais exatamente, aquêles funcionários estaduais e federais, cujos interêsses e responsabilidades se ligavam de uma forma ou de outra às relações com os indígenas, tinham, sem dúvida, observado o desenvolvimento do debate nas páginas d'O Estado de São Paulo e do Jornal do Commercio. Alguns entre êstes eram membros

\footnotetext{
(23). - O grifo fol acrescentado por Teixeira Mendes nesta publicação do Jornal do Commercio. Este artigo já fôra publicado antes, em 15 de dezembro, pela Igreja Positivista, sob o título: "O Scientismo e a defeza dos Indigenas brazileiros".

(24). - Jornal do Commercio de 19 de dezembro de 1908, pág. 4, cols. 5-6.
} 
efetivos ou correspondentes de uma ou mais das sociedades que tinham tomado parte na crescente controvérsia durante os meses passados. As autoridades estavam pois conscientes das críticas lançadas contra elas por terem falhado no estabelecimento de uma política indígena, em escala nacional, e por não terem tido boa vontade para tomar medidas para proteger ou os índios pacíficos ou os pioneiros na fronteira:

Até agora, durante o debate, a ênfase sôbre a conveniência da ação governamental estava sendo ofuscada pelos aspectos mais dramáticos da luta quase pessoal entre von Ihering e seus críticos. Não eram as críticas contra o Govêrno, mas antes os ataques contra o diretor do Museu Paulista, de origem alemã, e contra suas teorias científicas, que dominavam o primeiro estágio do debate indígena. Parcialmente por êste motivo, as solicitações para a intervenção governamental direta na questão indígena não eram suficientes, em 1908, para induzir as autoridades públicas à ação positiva .

O fato de ter o Govêrno brasileiro, dois anos mais tarde, assumido um papel dirigente nos negócios indígenas, pode ser atribuído, em grande parte, ao trabalho de indivíduos e Sociedades que mantiveram viva a questão da proteção e assimilação dos índios, durante o ano de 1909.

(Continua no próximo número).

\section{DAVID HALL STAUFFER}

Da Universidade do Texas, e atualmente do "Department of State" dos Estados Unidos da América do Norte. 